\title{
Экстракционно-хроматографическое определение серосодержащих аминокислот в биологических жидкостях
}

\author{
Никитин Д.А. ${ }^{1}$, Дутов А.А. ${ }^{2}$, Рудакова Л.В. ${ }^{3}$ \\ ${ }^{l}$ ФББОУ ВО «Воронежский государственный университет», Воронеж \\ ${ }^{2}$ ФГБОУ ВО «Читинская государственная медицинская академия», Чита \\ ${ }^{3}$ ФГБОУ ВО «Воронежский государственный медицинский университет», Воронеж
}

Поступила в редакцию 30.05.2017 г.

\begin{abstract}
Для целей клинических исследований предложен экстракционно-хроматографический способ определения аминотиолов (серосодержащих аминокислот) и глутатиона в биологических жидкостях с применением ВЭЖХ, включающий этап предколоночной дериватизации для возможности спектрофотометрического детектирования производных, а также восстановление присутствующих в организме окисленных форм аналитов. Для очистки и концентрирования проб использована твердофазная экстракция на сверхсшитом полистироле марки Purosep-200. Показана возможность применения разработанного способа для определения аминотиолов и глутатиона в сыворотке крови, слюне, цереброспинальной и слезной жидкостях, эритроцитах.
\end{abstract}

Ключевые слова: серосодержащие аминокислоты, ВЭЖХ, твердофазная экстракция, сверхсшитый полистирол Purosep-200.

\section{The extraction-chromatographic method for determining of sulfur containing amino acids in biological fluids}

\author{
Nikitin D.A. ${ }^{1}$, Dutov A.A. ${ }^{2}$, Rudakova L.V. ${ }^{3}$ \\ ${ }^{I}$ Voronezh State University, Voronezh \\ ${ }^{2}$ Chita State Medical Academy, Chita \\ ${ }^{3}$ Voronezh State Medical University, Voronezh
}

Sulfur-containing amino acids (SCAA) cysteine (Cys), homocysteine (Hcy) and tripeptide glutathione (GSH) are involved in many biochemical processes of the body. SCAA and glutathione are present in the body in two forms: in the form of oxidized derivatives (disulfides) and in free (reduced) form, the free forms being rapidly oxidized. To determine the total content of analytes, they must first be recovered from disulfides and protein conjugates. There are many ways to determine SCAA and glutathione by various methods including chromatographic ones. SCAA have a low molar absorption coefficient in the UV range, and therefore, for the spectrophotometric detection SCAA is subjected to pre-columnar derivatization. And the SCAA derivatives are detected after reaction with thiol-specific and nonspecific reagents. The use of a number of reagents (reducing agents, deproteinizers, antioxidants and derivatizing reagent) creates a problem for UV detection which high demands are placed on the purity of the extracts. In addition, the sequential addition of reagents results in a dilution of the bioassay.

In this study the extraction-chromatographic method is suggested for determining of sulfur- containing amino acids and gluthatione in biological fluids using HPLC with UV detection at $330 \mathrm{~nm}$. Reduction from disulfide bonds to thiol groups was carried out with 1,4-dithioerythritol. The derivatization of analytes was carried out with Ellman's reagent [5,5'-dithiobis (2-nitrobenzoic acid)]. Cartridges with hypercrosslinked polystyrene Purosep-200 were used for purification and concentration of samples. The results of HPLC determination of SCAA and gluthatione showed what purposed methods is characterized by simplicity of sample preparation, good reproducibility and sensitivity. This is makes this method suitable for routine 
clinical analysis, as well as for biochemical studies plasma and serum of the experimental animals - mice and rats, with uses small sample volumes of biological fluids.

Keywords: sulfur containing amino acids, HPLC, solid phase extraction, hyper-crosslinked polystyrene Purosep-200.

\section{Введение}

Серосодержащие аминокислоты (САК) - цистеин (Суs), гомоцистеин (Нсу) и трипептид глутатион (GSH) - участвуют во многих биохимических и патобиохимических процессах организма. Избыток гомоцистеина (гипергомоцистеинемия) повышает риск раннего развития атеросклероза и тромбоза артерий, а также развития разного рода депрессивных состояний, старческой деменции (слабоумия), болезни Альцгеймера и ряда других заболеваний [1-3]. Цистеин, образующийся из гомоцистеина через цистатионин, участвует в синтезе глутатиона [4]. Глутатион - это трипептид, являющийся наиболее мощным антиоксидантом, вырабатываемым самим организмом: он устраняет свободные радикалы, пероксиды липидов, предотвращает окисление биомолекул и способствует восстановлению других антиоксидантов [5-8].

САК и глутатион являются биологически и химически активными веществами и присутствуют в организме в двух формах: в виде окисленных производных дисульфидов (белковых конъюгатов (R1-S-S-R2)) и в свободной (восстановленной) форме (R-SH), причем свободные формы САК быстро окисляются [9, 10]. В зависимости от решаемых задач, возможно одновременное определение как свободных САК, так и суммы свободных САК и восстановленных форм из дисульфидов. Для определения общего содержания аналитов их необходимо предварительно восстановить из дисульфидов и белковых коньюгатов. В качестве восстанавливающих реагентов используют низкомолекулярные соединения, содержащие SH-группы (три-nбутилфосфин, 1,4-дитиоэритритол, дитиотрейтол и меркаптоэтанол), или борогидриды натрия или калия, выделяющие при разложении атомарный водород $[2,16]$.

Существует много способов определения САК и глутатиона различными химическими и инструментальными методами, в том числе хроматографическими. САК имеют низкий коэффициент молярного поглощения в УФ диапазоне [10, 2224], в связи с чем, для возможности спектрофотометрического детектирования САК подвергают предколоночной дериватизации и регистрируют производные САК после реакции с тиолспецифическими и неспецифическими реагентами [1, 2, 11-19].

Использование целого ряда реагентов (восстановителей из дисульфидов, депротеинизаторов, антиокислителей и дериватизирующого реагента) создает проблему для УФ детектирования, при котором предъявляются высокие требования к чистоте экстрактов. Кроме того, последовательное добавление реагентов приводит к разбавлению биопробы.

Возможно прямое определение САК и глутатиона методом ВЭЖХ, совмещенной с масс-спектрометром (МС-ВЭЖХ), а также с применением ВЭЖХ с амперометрическим детектором [1]. Однако, приборы МС-ВЭЖХ отличаются высокой стоимостью, требуют специальной высокой квалификации оператора, поэтому эти приборы пока не применяются в рутинном клиническом анализе.

Целью настоящей работы явилась разработка простого, воспроизводимого и чувствительного способа определения САК и глутатиона с применением ВЭЖХ с УФ-детектированием в биологических жидкостях (плазме/сыворотке крови, слюне, слезной и цереброспинальной жидкостях) и клетках (эритроцитах), пригодного как для экспериментальных исследований, так и для рутинного клинического анализа. Для решения задачи концентрирования и очистки аналита (устранения побочных продуктов дериватизационной реакции и других мешающих определению компо- 
нентов) предложено применение твердофазной экстракции на полимерном сорбенте Purosep-200.

\section{Эксперимент}

Реагенты и растворители. В работе применяли следующие реактивы: D,Lгомоцистеин (>95\%, Fluka), L-цистеин (>99\%, Sigma-Aldrich), цистеамин (>98\%, Fluka), N-ацетилцистеин (>99\%, Fluka), глутатион восстановленный (>98\%, SigmaAldrich), ацетонитрил «о.с.ч сорт 1» (Криохром), изопропанол «х.ч.» (Лекбиофарм), метанол (HPLC Grade, Merck), ортофосфорная кислота (>98\%, Fluka), лимонная кислота $(>98 \%$, Fluka) и трифторуксусная кислота (>98\%, Fluka), хлороформ и ацетон «х.ч.» (Синтакон), дихлорметан «о.с.ч» (Вектон), L-пеницилламин (>99\%, SigmaAldrich).

Исходные растворы аналитов (1 мг/см3) получали растворением точных навесок в $0.01 \mathrm{H} \mathrm{HCl}$ и хранили при $+4^{\circ} \mathrm{C}$. Рабочие растворы готовили путем последовательного разбавления исходных растворов деионизированной водой в день исследования.

В качестве дериватизационного реагента использовали тиолспецифичный реагент Эллмана - 5,5'-дитиобис-(2-нитробензойная кислота (рис. 1), выбор которого обусловлен коммерческой доступностью, коротким временем реакции и наиболее высокими хромофорными свойствами полученных производных. Он специфично реагирует с SH-группами в слабощелочной среде (pH 7.6-8.6), образующиеся продукты имеют коэффициенты молярной экстинкции от 12500 до 14290 при 330 нм. Дериватизационный реагент готовили растворением 20 мг реагента Эллмана в $1 \mathrm{~cm}^{3}$ $0.25 \mathrm{M}$ фосфатного буферного раствора (рH 8.0) и хранили в затемненном месте при комнатной температуре до 2 месяцев.

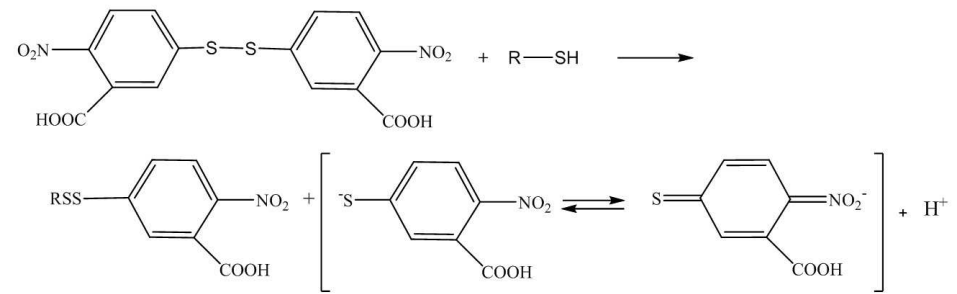

Рис. 1. Схема взаимодействия тиольных групп с реагентом Эллмана.

Восстанавливающим реагентом служил раствор 1,4-дитиоэритритола, который готовили растворением 2 мг 1,4-дитиоэритритола в 1 мл $0.25 \mathrm{M}$ фосфатного буферного раствора (рН 8.0) с добавлением 0.001 М ЭДТА и хранили при комнатной температуре до 1 месяца.

Оборудование. Исследования проводили с использованием высокоэффективного жидкостного хроматографа, в комплектацию которого входят: насос высокого давления («Shimadzu» LC-20AT Prominence), спектрофотометрический детектор («Shimadzu» SPD-20A Prominence), ручной инжектор («Rheodyne» 7725i). Обработку данных проводили с применением программного обеспечения («Амперсенд», Мультихром версия 3.0).

Условия хроматографического разделения. Хроматографическое разделение проводили на колонках с обращенно-фазными сорбентами: Luna (Phenomenex, USA), C18(2), длиной 150 мм и внутренним диметром 4.6 мм; Диасфер-110-С18 (БиоХимМак, Россия) длиной 50 мм и внутренним диаметром 4.0 мм. Размер частиц сорбентов 5 мкм. В качестве подвижной фазы использовали смесь: ацетонитрил - цитратно-фосфатный буферный раствор (рН 2.2) - изопропанол. Цитратно-фосфатный бу- 
ферный раствор готовили по Макилвейну [21], путем смешивания $0.1 \mathrm{M}$ лимонной кислоты и $0.2 \mathrm{M} \mathrm{Na}_{2} \mathrm{HPO}_{4}$ с последующим разбавлением дистиллированной водой до концентрации $0.05 \mathrm{M}$.

Твердофазную экстракцию (ТФЭ) проводили на картриджах на основе полипропиленовых шприцев объемом $3 \mathrm{~cm}^{3}$ с фторопластовыми фильтрами (Supel-co, USA), упакованных 30 мг сверхсшитого полистирола (Purosep-200). Для высушивания сорбента картриджей использовали вакуумный насос (KNF Lab, USA) и манифолд на 12 картриджей (Merck, Germany). Экстракты упаривали в стеклянных стаканчиках (Simax) на 5 cм $^{3}$ в термостате с пассивной конвекцией (Boekel Scientific, USA).

Для определения САК в сыворотке крови отбирали 400 мкл сыворотки, добавляли 200 мкл ДТТ и помещали в термостат на 15 мин при $50^{\circ} \mathrm{C}$. После охлаждения до комнатной температуры, добавляли 100 мкл внутреннего стандарта (Lпеницилламин, 10 нг/мкл), 100 мкл реагента Эллмана и выдерживали 10 мин. Затем добавляли 20 мкл $\mathrm{HClO}_{4}$, интенсивно перемешивали и центрифугировали 1 мин при $10.000 \mathrm{rpm}$. Весь супернатант вводили в картридж с сорбентом Purosep-200, предварительно кондиционированный $1 \mathrm{~cm}^{3}$ ацетона, $1 \mathrm{~cm}^{3}$ метанола и $1 \mathrm{~cm}^{3}$ воды. После ТФЭ сухой остаток растворяли в $0.05 \mathrm{M}$ фосфатном буферном растворе с $\mathrm{pH} 8.0$ и вводили в петлю инжектора 10 мкл (эквивалент $0.04 \mathrm{~cm}^{3}$ сыворотки).

При определении аминотиолов в слюне для устранения мешающей матрицы применяли следующий способ: пробу собирали в 2-мл полипропиленовые пробирки типа «Eppendorf», проводили этап вымораживания, центрифугировали 2-5 мин при $10.000 \mathrm{rpm}$. Полученный прозрачный раствор анализировали. Для анализа отбирали 400 мкл слюны, добавляли 200 мкл ДТТ и помещали в термостат на 15 мин при $50^{\circ} \mathrm{C}$. После охлаждения до комнатной температуры, добавляли 200 нг внутреннего стандарта (L-пеницилламина), 100 мкл реагента Эллмана и выдерживали 5 мин. Затем добавляли 50 мкл хлорной кислоты, интенсивно перемешивали и центрифугировали 1 мин при $10.000 \mathrm{rpm}$. Весь супернатант вводили в картридж. После проведения ТФЭ раствор упаривали, а сухой остаток растворяли в $0.05 \mathrm{M}$ фосфатном буферном растворе с рН 8.0 и вводили в петлю инжектора 25 мкл (эквивалент $0.1 \mathrm{~cm}^{3}$ слюны).

Определение САК и глутатиона в цереброспинальной жидкости проводили по описанной выше методике с учетом низкой концентрации САК и глутатиона в цереброспинальной жидкости. Для проведения исследования необходимо не менее $1 \mathrm{~cm}^{3}$ жидкости.

В случае со слезной жидкостью из-за ограниченного количества биологического материала провести ТФЭ и очистку невозможно. В этом случае к 25 мкл пробы

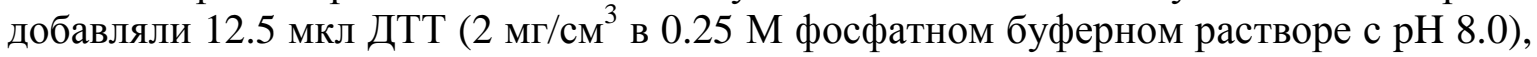
помещали в термостат на 15 мин при $50^{\circ} \mathrm{C}$. Затем добавляли 7 мкл реагента Эллмана, выдерживали 10 мин и вводили в петлю инжектора 22 мкл (эквивалент 0.013 мл слезы).

Определение глутатиона в эритроцитах проводили следующим способом._После отбора плазмы эритроциты отмывались 3-4 объемами физиологического раствоpa $(0.9 \% \mathrm{NaCl})$ путем переворачивания пробирки и центрифугировались 2 мин при $3000 \mathrm{rpm}$. Слой физиологического раствора выбрасывали. Процедуру повторяли до тех пор, пока надосадочный раствор не станет прозрачным. Если не проводилась немедленная обработка, отбирали 100 мкл эритроцитарной массы в 2-см ${ }^{3}$ полипропиленовую пробирку и хранили при $4^{\mathrm{O}} \mathrm{C}$ в течение не более 3 дней. Процедура гемолиза: к 100 мкл эритроцитарной массы добавляли 900 мкл воды и перемешивали. Отбирали по 400 мкл этого гемолизата для определения общего и свободного глутатиона. К 400 мкл гемолизата добавляли по 200 мкл ДТТ (при определении общего 
GSH) или 200 мкл 0.25 М фосфатного буферного раствора с pH 8.0 (при определении свободного GSH), смесь помещали в термостат на 15 мин при $50^{\circ} \mathrm{C}$. Затем добавляли один из внутренних стандартов - цистеамин (40 мкл, 100 нг/мкл) или L-пеницилламин (10 мкл, 100 нг/мкл), 100 мкл реагента Эллмана, перемешивали и выдерживали не менее 5 мин. После этого добавляли 50 мкл хлорной кислоты, перемешивали интенсивным встряхиванием и центрифугировали 1 мин при $10.000 \mathrm{rpm}$. Дальнейший анализ проводили двумя способами:

1) непосредственное введение 20 мкл экстракта в петлю инжектора со 100 нг внутреннего стандарта цистеамина (эквивалентно 0.0005 мл эритроцитарной массы);

2) твердофазная экстракция и очистка на полимерном сорбенте с 30 мг Purosep-200: в предварительно регенерированный картридж - последовательно $1 \mathrm{~cm}^{3}$ ацетона, $1 \mathrm{~cm}^{3}$ метанола и $1 \mathrm{~cm}^{3}$ воды. Весь объем экстракта (около $0.8 \mathrm{~cm}^{3}$ ) вводили в картридж со скоростью не более $1 \mathrm{~cm}^{3} /$ мин. Остальные этапы экстракции аналогичны обработке образцов плазмы крови.

\section{Обсуждение результатов}

В проведенном исследовании оценили возможность применения в качестве внутренних стандартов (IS) цистеамина, L-пеницилламина и $\mathrm{N}$-ацетилцистеина. Наиболее подходящим веществом оказался L-пеницилламин, который элюируется между цистеином и глутатионом. В случаях, когда не проводится ТФЭ, возможно использование цистеамина.

Для получения растворов производных аналитов смешивали по 10 мкл (100 нг/мкл) растворов САК, глутатиона и внутреннего стандарта, добавляли 40 мкл

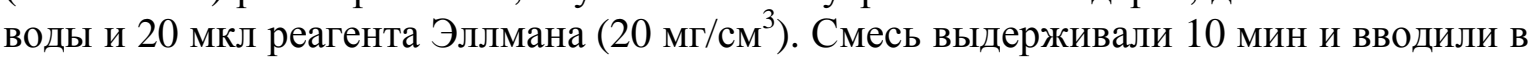
петлю инжектора 10 мкл. В ходе реакции образуется хиноидная форма аниона реагента Эллмана (TNB $\left.{ }^{-}\right)[15]$, которая характеризуется большим временем удерживания, чем производные, и дает на хроматограмме интенсивный пик (рис. 2.).

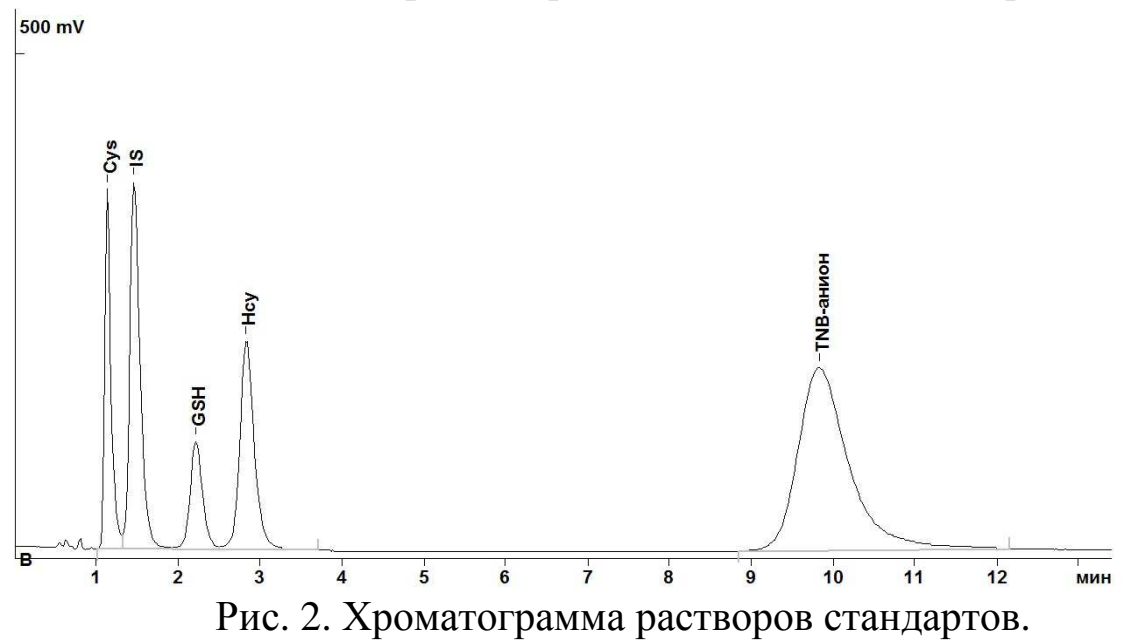

Колонка Диасфер-110-С18 50×4.0 мм, 5 мкм, УФ 330 нм, Подвижная фаза: ацетонитрил - 0.05 М цитратно-фосфатный буферный раствор с рH 2.1 - изопропанол (15:84:1, об.), 1000/мин, IS - цистеамин.

Поскольку последовательное добавление используемых реагентов приводит к разбавлению ограниченного объема биопробы, определение САК и глутатиона в слюне, слезной и цереброспинальной жидкостях, а также биологических жидкостях экспериментальных животных (крыс, мышей) возможно только с применением концентрирования. 
В связи с тем, что нативные САК и глутатион являются полярными веществами, ТФЭ из биологической матрицы на обращенно-фазовых сорбентах на основе модифицированных силикагелей $(\mathrm{C} 18, \mathrm{C} 8$ и т.д.) является неэффективной. По этой же причине не удалось подобрать эффективные условия жидкостно-жидкостной экстракции САК и глутатиона из биологических жидкостей по методике [10]. Решение проблемы возможно с помощью существующих специфических полимерных сорбентов, обеспечивающих свойства обращенно-фазового сорбента, однако они имеют высокую стоимость и допускают только одноразовое использование [18]. В нашей работе для ТФЭ был использован сверхсшитый полистирол (Purosep-200), разработанный В.А. Даванковым и М.П. Цюрупой [22]. Перед началом работы с биологическими жидкостями были предварительно найдены рабочие условия загрузки и элюирования производных на растворах стандартов. Установлено, что полная сорбция производных САК и глутатиона из $1 \mathrm{~cm}^{3}$ анализируемого раствора происходит на сорбенте массой 30 мг в кислой среде. Производные полностью элюируются с сорбента в щелочной среде (1 $\mathrm{cm}^{3}$ метанола с $1 \%$ содержанием аммиака). При анализе биологических проб, содержащих фоновые вещества, для промывки сорбента, использовали $1 \mathrm{~cm}^{3}$ воды.

Устранить мешающее влияние биологической матрицы возможно и с помощью селективного растворения упаренного элюата пробы. Установлено, что дериваты САК достаточно термостабильны и полностью сохраняются при упаривании в метаноле при $60-70^{\circ} \mathrm{C}$, а оптимальный растворитель - $0.05 \mathrm{M}$ фосфатный буфер с $\mathrm{pH}$ 8.0.

Градуировочные зависимости были получены для растворов стандартов в

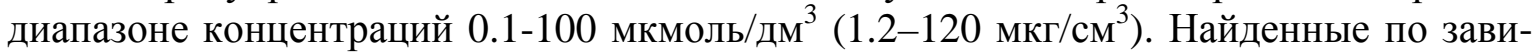
симостям пределы количественного определения составляют 0.4 нг для гомоцистеина и глутатиона; 0.3 нг для цистеина.

Определение САК в сыворотке крови. САК и глутатион стабильны в сыворотке при хранении в течение 1 недели при $+4^{\circ} \mathrm{C}$. В замороженном виде они сохраняются до 3 месяцев. Для обработки сыворотки крови использовали восстанавливающий реагент 1,4-дитиоэритритол (ДТТ) с концентрацией $2 \mathrm{мг} / \mathrm{cm}^{3}$ в $0.25 \mathrm{M}$ фосфатном буферном растворе (pH 8.0). В приготовленный реагент обязательно добавляют $0.3 \mathrm{мг} / \mathrm{cm}^{3}$ ЭДТА для предотвращения окисления высвободившихся САК. Увеличение концентрации более $10 \mathrm{Mг} / \mathrm{cm}^{3}$ приводит к появлению дополнительных пиков на хроматограмме и уменьшению высоты пиков производных аминотиолов, вплоть до их полного исчезновения. Возможная причина этого в том, что часть реагента Эллмана расходуется на дериватизацию самого ДТТ.
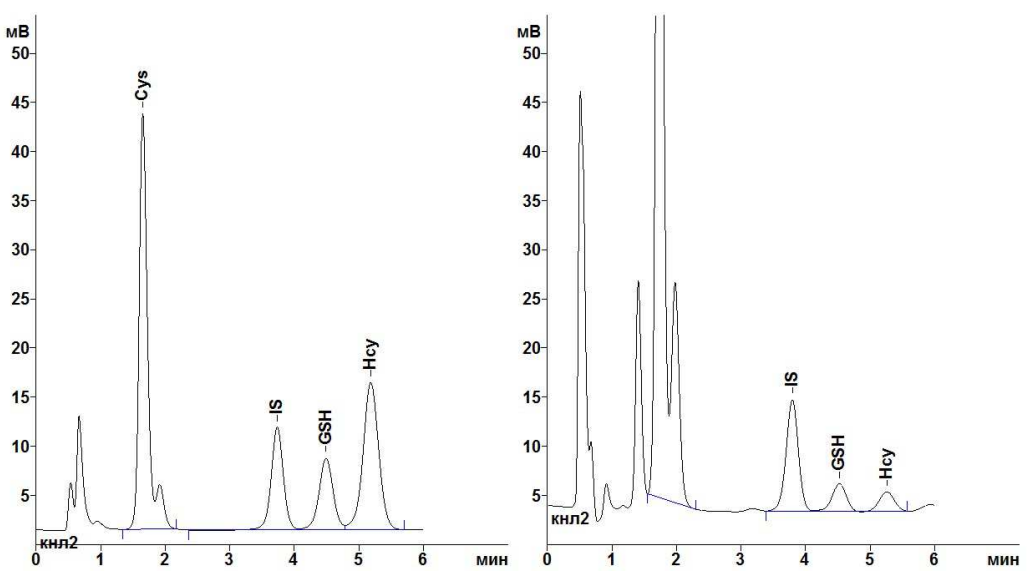

Рис. 3. Хроматограммы растворов стандартов и экстракта сыворотки.

Колонка Диасфер-110-С18, 50 × 4.0 мм, 5 мкм, УФ 330 нм. Подвижная фаза: ацетонитрил-цитратнофосфатный буферный раствор-изопропанол- 0.05 .

Никитин и др. / Сорбционные и хроматографические процессы. 2017. Т. 17. № 4 
Были проанализированы образцы свежих сывороток крови от 20 здоровых добровольцев (пример на рис. 3). Результаты определения гомоцистеина во взятых образцах, полученных с помощью разработанной методики, были сопоставлены с результатами иммуноферментного анализа на наборах для гомоцистеина фирмы «Вектор Бест» (табл.1). Кроме того, методом ВЭЖХ определено содержание цистеина, который с помощью данного набора для ИФА не определяется. Глутатион в данном исследовании не определялся.

Таблица 1. Примеры результатов определения цистеина (Суs) и гомоцистеина (Нсу)

\begin{tabular}{|c|c|c|c|}
\hline ФИО & Тиолы & $\begin{array}{c}\text { Содержание, (ВЭЖХ) } \\
\text { мкмоль/дм }^{3}\end{array}$ & $\begin{array}{c}\text { Содержание, (ИФА) } \\
\text { мкмоль/дм }\end{array}$ \\
\hline \multirow{2}{*}{ Б. В., 20 лет } & Cys & $155 \pm 5$ & \\
\hline & Hcy & $10.3 \pm 0.5$ & 10.5 \\
\hline \multirow{2}{*}{ Х. С, 19 лет } & Cys & $157 \pm 5$ & \\
\hline & Hcy & $9.0 \pm 0.4$ & 9.5 \\
\hline \multirow{2}{*}{ Ш. А, 18 лет } & Cys & $164 \pm 6$ & \\
\hline & Hcy & $9.8 \pm 0.5$ & 10.8 \\
\hline \multirow{2}{*}{ К. А, 17 лет } & Cys & $181 \pm 7$ & \\
\hline & Hcy & $14.0 \pm 0.7$ & 13.7 \\
\hline \multirow{2}{*}{ М. А, 19 лет } & Cys & $180 \pm 7$ & \\
\hline & Hcy & $9.5 \pm 0.5$ & 10.3 \\
\hline \multirow{2}{*}{ П. А, 19 лет* } & Cys & $152 \pm 5$ & \\
\hline & Hcy & $48.0 \pm 3$ & 49.2 \\
\hline
\end{tabular}

*Испытуемая с хронической почечной недостаточностью

Определение аминотиолов в слюне. В сыворотке крови концентрация гомоцистеина в 15-20 раз ниже концентрации цистеина, по литературным данным уровень гомоцистеина в слюне еще примерно в 10 раз ниже, чем в сыворотке. Таким образом, анализ САК и глутатиона в слюне возможен только с использованием ТФЭ, которая позволяет сконцентрировать пробу. Результаты ВЭЖХ анализа представлены на рис. 4.
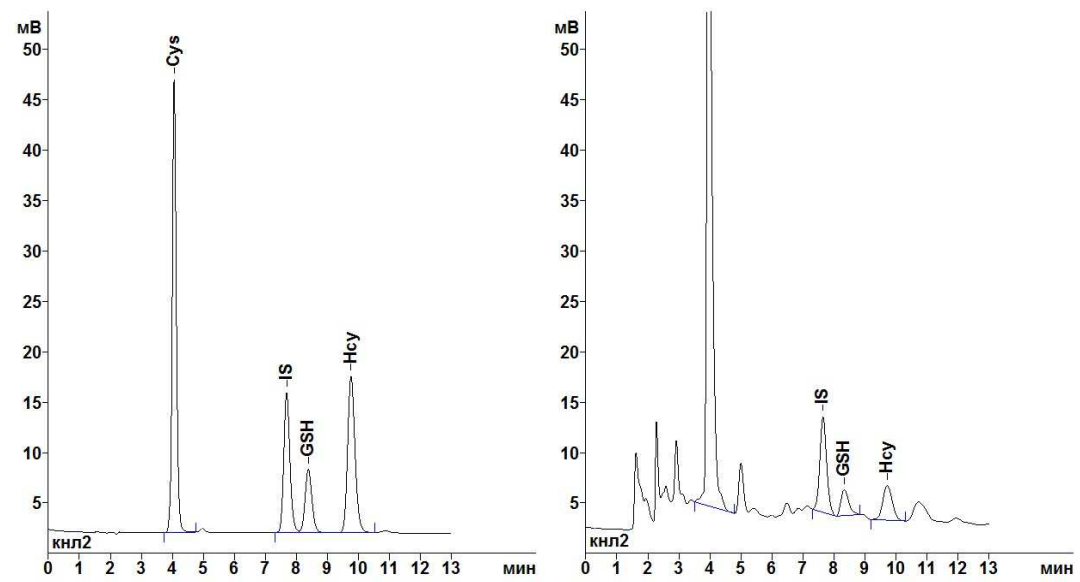

Рис. 4. Хроматограммы растворов стандартов и экстракта слюны.

Колонка Phenomenex Luna C18(2) 150 × 4.6 мм, 5 мкм, УФ 330 нм. Подвижная фаза: ацетонитрил 0.05 М лимонная кислота (15:85, об.), 1000/мин, IS - L-пеницилламин.

Определение САК и глутатиона в цереброспинальной и слезной жидкостях. С учетом низкой концентрации САК и глутатиона в цереброспинальной жидкости определение возможно проводить по описанной выше методике. Важным условием 
проведения исследования является отсутствие гемолиза в цереброспинальной жидкости. В противном случае получаются завышенные концентрации глутатиона, который высвобождается из разрушенных эритроцитов. Пример полученных хроматограмм приведен на рис. 5.
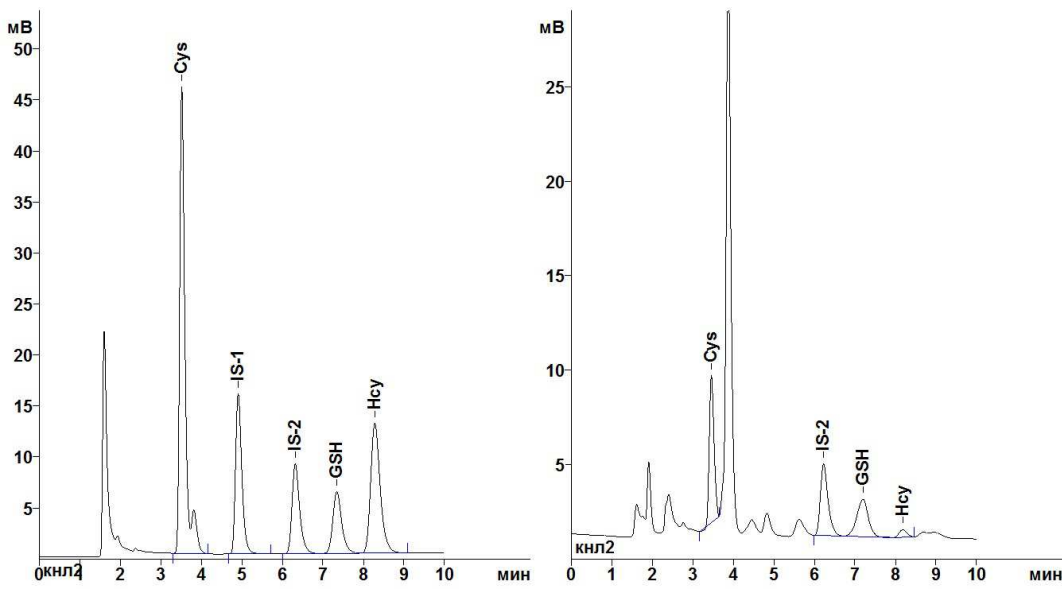

Рис. 5. Хроматограммы растворов стандартов и экстракта цереброспинальной жидкости.

Колонка Phenomenex Luna C18(2) $150 \times 4.6$ мм, 5 мкм, УФ 330 нм, подвижная фаза: ацетонитрил - 0.05 М цитратно-фосфатный буферный раствор с рН 2.2 (15:85, об.), 1000/мин, IS-1 - цистеамин, IS-2 - L-пеницилламин.

В случае со слезной жидкостью рассмотрена принципиальная возможность применения разработанной методики, но из-за ограниченного количества биологического материала провести ТФЭ и очистку невозможно.

Определение глутатиона в эритроцитах. Глутатион является преимущественно внутриклеточным компонентом. Концентрация его в плазме/сыворотке крови низкая, а в эритроцитах на несколько порядков выше. Здесь он представлен в двух формах: окисленный (GSSG) и восстановленный или свободный (GSH). Преобладает свободный GSH, а на долю окисленного приходится 10\% и менее [24]. Для перевода GSSG в GSH используют ДТТ и после такой обработки получают общий GSH. Без обработки ДТТ анализируют свободный GSH.

На рис. 6 приведены результаты анализа экстракта эритроцитарной массы после твердофазной экстракции. В отличие от других биологических жидкостей (плазмы/сыворотки крови, слюны) в экстракте эритроцитов практически отсутствуют «мешающие» пики, а концентрация глутатиона очень высокая, и поэтому можно обойтись без ТФЭ и концентрирования. Однако она может быть полезной при крайне ограниченном количестве биологического материала, когда необходимо сконцентрировать экстракт.

По полученным данным концентрация общего и свободного глутатиона в

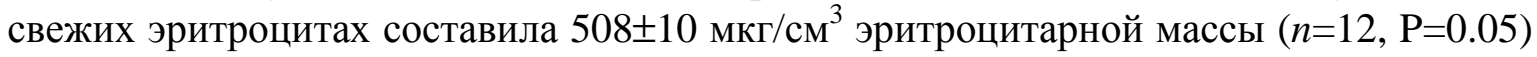
и $455 \pm 15(n=12, \mathrm{P}=0.05)$. В сыворотке содержание глутатиона составляет $0.57 \pm 0.06$ $(n=10, \mathrm{P}=0.05)$, т.е. практически в 1000 раз меньше.

Важное значение имеют условия хранения биологического материала. Так, в замороженной/размороженной эритроцитарной массе концентрация общего GSH примерно на $10 \%$ меньше, чем в свежих эритроцитах, не подвергнутых заморозке. А в замороженном гемолизате содержание GSH свободного в 2.5 раза меньше в сравнении с гемолизатом, хранившимся при $+4^{\circ} \mathrm{C}$. 

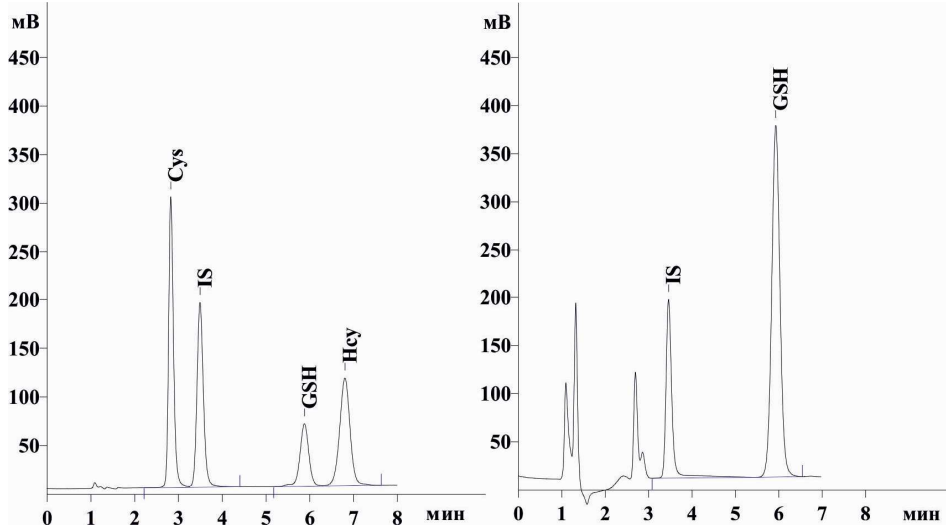

Рис. 6. Хроматограммы растворов стандартов и экстракта эритроцитарной массы после твердофазной экстракции.

Колонка Диасфер-110-С18 50 × 4 мм, 5 мкм. Подвижная фаза: ацетонитрил - 0.05 М лимонная кислота (12:88, об.), скорость потока 1000 мкл/мин, IS - цистеамин.

\section{Заключение}

Предложенный способ определения серосодержащих аминокислот и глутатиона методом ВЭЖХ с УФ-детектированием продуктов их предколоночной дериватизации после предварительной очистки и концентрирования методом ТФЭ на сверхсшитом полистироле Purosep-200 является сравнительно простым по процедуре пробоподготовке, воспроизводимым и, в достаточной мере, чувствительным, позволяет проводить определения с ошибкой не более $\pm 10 \%$. Способ пригоден для рутинного применения в клиническом анализе не только плазмы/сыворотки, крови, но и слюны, мочи, слезной и цереброспинальной жидкостей, а также для биохимических исследований плазмы/сыворотки крови экспериментальных животных - крыс и мышей, с малым объемом проб.

\section{Список литературы}

1. Яшин А., Немзер В., Веденин А., Яшин Я. // Аналитика. 2016. № 6. С. 80-86.

2. Ueland P. M., Refsum H., Stabler S.P., Malinow R.M. et al. // Clinical Chemistry. 1993. Vol. 39. № 9. pp. 1764-1779.

3. Шевченко О.П., Олефиренко Г.А. // Лаборатория. 2002. № 1. С. 3-6.

4. Melnyk S. Pogribna M., Pogribny I.P., Yi P. et al. // Clinical Chemistry. 2000. Vol. 46. pp. 265-272.

5. Биохимия / под ред. Е.С. Северина. М. ГЭОТАР-Медиа. 2005.784 с.

6. Cacciatore I., Cornacchia C., Pinnen F., Mollica A. et al. // Molecules. 2010. Vol. 15. pp. 1242-1264. doi:10.3390/molecules15031242.

7. Wu G. Fang Y-Z., Yang S., Lupton J.R. et al. // Journal of Nutrition. 2004. Vol. 134. pp. 489-492.

8. Townsend D.M., Tew K.D., Tapiero H. // Biomedicine \& Pharmacotherapy. 2003. Vol. 57. pp. 145-155.
9. Рудаков О.Б., Селеменев В.Ф., Рудакова Л.В. ВЭЖХ. Сорбаты, сорбенты и элюенты. Воронеж: ВГАСУ. 2016. 205 с.

10. Спутник хроматографиста. Методы жидкостной хроматографии / Рудаков О.Б. [и др.]. Воронеж: Водолей. 2004. 526 с.

11. Рудаков О.Б., Хорохордина Е.А., Рудакова Л.В., Грошев Е.Н. // Вестник ВГУ. Серия: Химия. Биология. Фармачия. 2015. № 3. C. $42-47$.

12. Winters R.A., Zukowski J., Ercal N., Matthews R.H. et al. // Anal. Biochem. 1995. Vol. 227. pp. 14-21.

13. Lynn G., Hellwig L.C. Handbook of derivatization reactions for HPLC. John Wiley \& Sons. Inc. 1998. 1795 p.

14. Amores-Sanchez M.I., Medina M.A. // Clin. Chem. Lab. Med. 2000. Vol. 38(3). pp. 199-204.

15. Zhloba A., Blashko E. // J. Chromatogr. B. Analyt. Technol. Biomed. Life Sci. 2004. Vol. 
$800(1-2)$.

pp.

275-280

doi: 10.1016/j.jchromb.2003.10.048.

16. Gilfix B.M. // Clin. Chem. 1997. Vol. 43. pp. 687-688. doi:10.2527/jas.2006-523

17. Hyland K., Bottiglieri T // J. Chromatogr. 1992. Vol. 579. pp. 55-62.

18. Waters Oasis Sample preparation product (Application Notebook), (Water Corporations www.waters.com).

19. Tcherkas Y.V., Denisenko A.D. // Journal of Chromatography A. 2001. Vol. 913. pp. 309313.

20. Andersson A., Isaksson A., Brattstrom L., Hultberg B. // Clinical Chemistry. 1993. Vol. 39. pp. 1590-1597.

\section{References}

1. Yashin A., Nemzer B., Vedenin A., Yashin Ya., Analitika, 2016, No 6, pp. 80-86 (in Russian).

2. Ueland P.M., Refsum H., Stabler S.P., Malinow R.M., Andersson A. and Allen R.H. // Clinical Chemistry, 1993, Vol. 39, No 9, pp. 1764-1779.

3. Shevchenko O.P., Olefirenko G.A., Laboratoriya, 2002, No 1, pp. 3-6 (in Russian).

4. Melnyk S., Pogribna M., Pogribny I.P., Yi P. et al., Clinical Chemistry, 2000, Vol. 46, pp. 265-272.

5. Severin E.S. Biokhimiya [Biochemistry]. M., GEOTAR - Media, 2005. 784 p. (in Russian).

6. Cacciatore I., Cornacchia C., Pinnen F., Mollica A. et al., Molecules, 2010, Vol. 15, pp. 1242-1264.

7. Wu G., Fang Y-Z., Yang S., Lupton J.R et al., Journal of Nutrition, 2004, Vol. 134, pp. 489-492.

8. Townsend D.M., Tew K. D., Tapiero H., Biomedicine \& Pharmacotherapy, 2003, Vol. 57, pp. 145-155.

9. Dawson P, Elliott D Elliott Y, Jones K. Spravochnik biokhimika [Handbook of biochemist]. Moscow, Mir, 1991. 544 p (in Russian).

10. Jones D.P., Methods Enzymol, 2002, Vol. 348, pp. 93-112.

11. Rudakov O.B., Selemenev V.F., Rudakova L.V., HPLC. Sorbaty, sorbenty i elyuyenty [Sorbate, sorbent and eluent]. Voronezh, VGASU, 2016, 205 c. (in Russian).

12. Rudakov O.B., Selemenev V.F., Vostrov I.A. Sputnik khromatografista. Metody zhid-
21. Справочник биохимика (пер. с англ.) / Досон Р. и др.. М. Мир. 1991. 544 с.

22. Jones D.P. // Methods Enzymol. 2002. Vol. 348. pp. 93-112.

23. Цюрупа М.П., Блинникова З.К., Проскурина Н.А., Пастухов А.В и др. // Российские нанотехнологии. 2009. Т. 4. № 9-10. С. 109-117.

24. Дутов А.А., Никитин Д.А., Терешков П.П., Мартынова А.В. и др. // Вопросы биологической, медииинской и фармачевтической химии. 2015. № 6. С. 12-15.

kostnoy khromatografii [Handbook of chromatography. Liquid chromatography methods]. Voronezh: Vodoley, 2004, 526 p. (in Russian).

13. Rudakov O.B., Khorokhordina E.A., Rudakov L.V. Groshev E.N., Vestnik VGU. Seriia: Khimiia. Biologiia. Farmatsiia, 2015, Vol. 3, pp. $42-47$ (in Russian).

14. Winters R.A., Zukowski J., Ercal N., Matthews R.H. et al., Anal. Biochem, 1995, Vol. 227, pp. 14-21.

15. Lynn G., Hellwig L.C. Handbook of derivatization reactions for HPLC. John Wiley \& Sons, Inc., 1998, 1795 p.

16. Amores-Sanchez M.I., Medina M.A., Clin. Chem. Lab. Med, 2000, Vol. 38(3), pp. 199-204.

17. Zhloba A., Blashko E., J. Chromatogr. B. Analyt. Technol. Biomed. Life Sci., 2004, Vol. 800(1-2), pp. 275-280.

18. Gilfix B.M. Novel reductant for determination of total plasma homocysteine. Clin. Chem., 1997, Vol. 43, pp. 687-688.

19. Hyland K., Bottiglieri T., J. Chromatogr, 1992, Vol. 579, pp. 55-62.

20. Waters Oasis Sample preparation product (Application Notebook), (Water Corporations www.waters.com).

21. Tcherkas Y.V., Denisenko A.D., Journal of Chromatography A, 2001, Vol. 913, pp. 309313.

22. Andersson A., Isaksson A., Brattstrom L., Hultberg B., Clinical Chemistry, 1993, Vol. 39, pp. 1590-1597.

23. Tsyurupa M.P., Blinnikova Z.K., Proskurina N.A., Pastukhov A.V et al., Rossiyskiye nanotekhnologii [Russian nanotechnologies], 
2009, Vol. 4, No 9-10, pp. 109-117 (in Russian).

24. Dutov A.A., Nikitin D.A., Tereshkov P.P., Martynova A.V. et al., Problems of biological,

Никитин Денис Александрович - аспирант кафедры аналитической химии Воронежского государственного университета, Воронеж

Дутов Алексей Александрович - д.м.н., старший научный сотрудник НИИ молекулярной медицины при Читинской государственной медицинской академии, Чита

Рудакова Людмила Васильевна - д.х.н., доцент, заведующий кафедрой фармацевтической химии и фармацевтической технологии Воронежского государственного медицинского университета, Воронеж medical and pharmaceutical chemistry, 2015, No 6, pp. 12-15 (in Russian).

Nikitin Denis A. - the postgraduate student, department of analytical chemistry, chemical faculty, Voronezh State University, Voronezh

Dutov Alexey A. - doctor of science, department of Molecular medicine, Chita State Medical Academy, Chita

Rudakova Lyudmila V. - doctor of science, head of Department of pharmaceutical chemistry and pharmaceutical technology, pharmaceutical faculty, Voronezh State Medical University, Voronezh, e-mail: vodoley65@mail.ru 